\title{
Relasi Antara Penokohan Tokoh Utama dan Alur Pada Film Forget Me Not
}

\author{
Khrisna Bayu Kurnianto*, Haryono, Eko Kurniawan \\ Program Studi Sastra Jepang, Universitas Jenderal Soedirman, Purwokerto, Indonesia
}

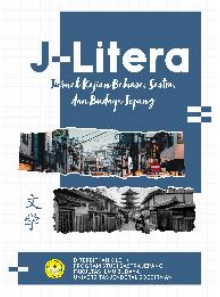

\begin{abstract}
The purpose of this research is to discribe the characterization of the main characters, the plot in the film with a tittle Forget Me Not, and to determine a relationship between those two elements. Author used structuralism theory to analyze characterization of main character, plot, and the relation between those two elements. Furthermore, the analysis arranged using descriptive qualitative method. The data source of this research is a film with a tittle Forget Me Not, and using dialog and scene in these film to analyze it. Referring and taking notes is a method to collecting data and using structural and narrative method to analyze the data. Based on the analysis, the result of this research are the main character in the film Forget Me Not is Oribe Azusa and Hayama Takashi. Oribe Azusa has a kind, mysterious and resign characterization. Meanwhile Hayama Takashi has a faithful and liar characterization. The plot in these film is a progressive plot. And the characterization of the main character and the plot in a film called Forget Me Not is interrelated each other until the story in these film can go trough to the final stage.
\end{abstract}

Keywords:

Characterization; plot;

relation; structuralism analysis

Article Info:

First received:

17 November 2019

Available online:

30 November 2019

\section{PENDAHULUAN}

Perkembangan pesat teknologi sekarang ini memungkinkan seseorang dapat menyampaikan buah pikir, ide, gagasan, maupun sebuah karya melalui media visual. Contoh karya yang dibuat melalui media visual adalah film. Film merupakan sebuah karya seni yang direkam dengan menggunakan media yang dapat memunculkan gerak, gambar, serta bunyi sehingga memiliki pemaknaan naratif yang dapat dimengerti oleh penontonnya (Susanti, 2017: 319), dengan media film sebuah karya dapat dinikmati secara lebih hidup. Film merupakan buah hasil dari sastra karena pembuatan film melibatkan skrip naskah cerita yang dimana di dalam skrip naskah cerita tersebut terdapat pula unsur pembentuk karya sastra seperti pada sebuah sastra naratif.

Seperti halnya dengan karya sastra naratif lainnya seperti cerpen dan novel, film juga memiliki unsur-unsur yang membangun karya sastra itu sendiri. Unsur yang dimaksud disini adalah unsur intrinsik dan ekstrinsik (Susanti, 2017: 319). Karena pembuatan film memerlukan naskah dan skrip, tentunya film juga memiliki kedua unsur tersebut seperti halnya cerpen dan novel. Unsur intristik adalah unsur-unsur yang secara langsung turut serta membangun cerita. Perpaduan berbagai unsur intrinstik inilah yang membuat film atau karyakarya sastra yang lainnya bisa terwujud. Unsur yang dimaksud adalah seperti, alur, peristiwa, cerita, plot, penokohan, tema, latar, dan sudut pandang (Nurgiyantoro, 2013: 30) 
Alur merupakan unsur fiksi yang penting, bahkan tidak sedikit orang yang menganggapnya sebagai yang terpenting di antara berbagai unsur fiksi yang lain. Alur menurut Stanton adalah cerita yang berisi urutan kejadian, namun urutan kejadian tersebut hanya dihubungkan secara sebab akibat (2007: 26). Alur merupakan unsur fiksi yang penting karena alur adalah tulang punggung sebuah cerita. Alur mempengaruhi segala unsur yang terdapat pada sebuah karya fiksi, namun alur juga tidak akan terjadi jika tidak ada unsur-unsur lain yang membentuk sebuah karya fiksi. Contoh paling mendasar adalah alur tidak akan berjalan jika tidak ada tokoh dan penokohan dalam sebuah karya fiksi. Tokoh adalah pelaku dalam sebuah cerita, sedangkan penokohan adalah merujuk pada sifat dan emosi dari tokoh (Stanton, 2007: 33). Tokoh dan Penokohan juga merupakan unsur fiksi yang penting, karena tanpa adanya tokoh maka cerita tidak akan berjalan. Tanpa penokohan, alur yang sebelumnya telah dibuat tidak akan bisa berjalan.

Film "Forget Me Not" adalah film yang diangkat dari novel dengan judul "Wasurenai to Chikatta Boku ga Ita" karya Mizuho Hirayama yang diterbitkan pada tahun 2007. Film ini disutradarai oleh Kei Horie yang dirilis pada tahun 2015. Forget Me Not sendiri bercerita seorang anak laki-laki biasa bernama Hayama Takashi yang jatuh cinta kepada teman satu sekolahnya bernama Oribe Azusa. Azusa bukanlah seorang gadis biasa, dia mengalami suatu kejadian aneh didalam hidupnya yaitu dia dilupakan oleh orang yang mengenal dirinya, bahkan orang tuanya sendiri pun melupakannya. Azusa kemudian menceritakan hal tersebut kepada Takashi. Namun Takashi tidak mempercayainya.

Diketahui bahwa Azusa adalah tokoh utama dalam film tersebut. Tokoh utama adalah tokoh yang paling diutamakan penceritaannya, baik sebagai pelaku kejadian maupun yang dikenai kejadian dan konflik (Nurgiyantoro, 2013:177). Karena tokoh utama paling banyak diceritakan dan berhubungan dengan tokoh-tokoh lain, ia sangat menentukan perkembangan alur secara keseluruhan. Di film Forget Me Not, Azusa merupakan salah satu pusat dari inti cerita keseluruhan film karena ia-lah tokoh yang dikenai kejadian dan konflik utama dari film tersebut. Konflik utama dari film tersebut adalah dilupakannya Azusa oleh orang-orang seperti apa yang telah dijelaskan sendiri olehnya kepada Takashi

Jika mengacu pada istilah "No Conflict, No Stories" maka peran Azusa disini sebagai tokoh utama sangatlah penting, karena jika tidak, maka tidak akan ada cerita atau alur dari film tersebut. Nurgiyantoro menyatakan bahwa penokohan dan alur merupakan dua fakta cerita yang saling mempengaruhi dan menggantungkan satu dengan yang lain (2013:172-173). Alur adalah apa yang dilakukan tokoh dan apa yang menimpanya. Kejadian demi kejadian yang ada, ketegangan, konflik, dan sampai ke klimaks yang semuanya adalah hal yang penting dalam alur hanya mungkin terjadi jika ada pelakunya.

Alur memiliki tahapan-tahapan. Menurut Tasrif (dalam Nurgiyantoro, 2013:149) tahapan-tahapan dalam alur adalah tahap penyituasian, tahap pemunculan konflik, tahap peningkatan konflik, tahap klimaks, dan tahap penyelesaian, namun dalam film Forget Me Not tahapan tersebut hanya berhenti pada tahap klimaks tidak ada penyelesaian dan ending dari cerita film tersebut seperti menggantung. tahap klimaks ini terjadi ketika Takashi berjanji untuk menemui Azusa, namun ketika Takashi bertemu dengan Azusa, Takashi sama sekali tidak mengenali Azusa yang sebenarnya sudah ada di depan matanya. Berdasarkan hal tersebut bisa diambil kesimpulan bahwa Takashi telah melupakan Azusa. Setelah percakapan itu selesai, Azusa pun pergi menghilang dan cerita pun menggantung. Selain memiliki tahapantahapan, alur juga memiliki kaidah. Hal yang paling penting dalam kaidah alur adalah plausibilitas atau kelogisan. Di film Forget Me Not tidak ada kaidah plausibilitas, karena dilupakannya Azusa sama sekali tidak dijelaskan atau mungkin dijelaskan namun secara tersirat lewat alur yang maju dan mundur, sehingga alur dalam film ini terlihat 
rumit dan kompleks namun tetap menarik untuk disaksikan. Karena hal itulah peneliti meresa tertarik untuk menjadikan film Forget Me Not sebagai objek penelitian. Untuk memahami cerita yang rumit dan kompleks, pemahaman terhadap relasi atau atau prinsipprinsip antarhubungan setiap unsur sangat dibutuhkan. Seperti yang diketahui, setiap unsur dalam sebuah cerita fiksi tidaklah berdiri sendiri, dan unsur-unsur tersebut saling berkaitan satu dengan yang lain. Tanpa antarhubungan sesungguhnya unsur-unsur dalam cerita fiksi seperti alur dan penokohan tidaklah berarti (Ratna, 2010: 77). Untuk memahami keterkaitan relasi antara penokohan tokoh utama dan alur pada film Forget Me Not, penulis menggunakan teori strukturalisme yang nantinya terfokus pada penokohan tokoh utama dan alur serta relasi antara kedua unsur tersebut.

\section{TINJAUAN PUSTAKA}

\section{Strukturalisme}

Kajian tentang strukturalisme meliputi cakupan yang luas dan melibatkan banyak ahli sastra dan linguistik. Teori Strukturalisme adalah teori yang dipelopori oleh kaum Formalisme Rusia dan Strukturalisme Praha. Teori Strukturalisme juga mendapatkan pengaruh langsung dari teori Saussure mengenai mengubah studi linguistik dari pendekatan diakronik ke sinkronik dan dijadikan kajian polemik tentang teori puisi antara Jacobson dan Levi-Strauss versus Riffaterre. Jadi diskusi mengenai strukturalisme memerlukan waktu yang panjang karena berkaitan dengan banyak aspek dalam kehidupan bersastra.

Sebuah teks sastra menurut pandangan kaum Strukturalisme adalah totalitas yang dibangun secara utuh dari oleh berbagai unsur pembangunnya. Abrams (Dalam Nurgiyantoro, 2013: 57) mengatakan bahwa struktur karya dapat diartikan sebagai susunan, penegasan, dan gambaran semua bahan dan bagian yang menjadi komponen yang secara bersama membentuk kebulatan yang indah. Setiap teks naratif sastra memiliki sebuah struktur khas yang menjadi tanda kehadirannya. Hal itulah yang membedakannya dengan teks-teks yang lain. Struktur teks itu mengorganisasikan berbagai elemen yang saling berhubungan antara satu dengan yang lain. Struktur itulah yang menjadikan sebuah teks naratif bermakna, masuk akal, logis, dan dapat dipahami. Ryan dan Tyson (Dalam Nurgiyantoro) mengatakan bahwa struktur dapat dipahami sebagai sistem aturan yang menyebabkan berbagai elemen itu membetuk sebuah kesatuan yang bersistem sehingga bermakna. Jika membaca cerita fiksi, kita akan bertemu dengan berbagai tokoh dan peristiwa yang dikenakan oleh para tokoh , tempat, waktu, dan latar belakang sosial budaya di mana cerita tersebut terjadi. Semuanya tampak berjalan serentak dan saling berhubungan karena ada benang merah yang mengatur dan menguhubungkan semua struktur tersebut.

Strukturalisme memiliki tujuan untuk memaparkan secermat dan sedetail mungkin fungsi dan keterkaitan antarberbagai unsur karya sastra. Analisis struktural tidak cukup pada mendata unsur tertentu karya fiksi, namun yang paling penting adalah menunjukan keterkaitan antar unsur fiksi tersebut tentang tujuan makna estetik dan makna keseluruhan dari karya yang terkait (Nurgiyantoro, 2013: 57). Strukturalisme memberikan perhatian terhadap kajian unsurunsur teks kesastraan. Analisis struktural karya sastra, yang dalam hal ini fiksi adalah fokus pada unsur-unsur instrinsik pembangunnya. Ia dapat dilakukan dengan mengidentifikasi dan mendeskripsikan bagaimana keadaan peristiwa, alur, tokoh dan penokohan, latar sudut pandang, dan lain-lain. Setelah dijelaskan bagaimana fungsi masing-masing unsur itu dalam menunjang makna secara keseluruhan, dan bagaimana hubungan antarunsur itu sehingga secara bersama membentuk sebuah totalitas kemaknaan yang padu. Analisis struktural dapat berupa kajian yang menyangkut relasi unsur-unsur mikroteks, satu keseluruhan wacana dan relasi intertekstual (Hartoko dan Rahmanto dalam Nurgiyantoro, 2013 : 60). Analisis unsur-unsur mikroteks itu misalnya berupa analisis fungsi dan hubungan antara unsur latar waktu, tempat 
dan sosial yang intinya adalah unsur intrinsik. Unsur intrinsik yang terdapat dalam karya sastra adalah tema, cerita, alur, tokoh dan penokohan, dan latar.

\section{Tokoh dan Penokohan}

Dalam pembicaraan sebuah cerita fiksi, sering dipergunakan istilah-istilah seperti tokoh dan penokohan watak dan perwatakan. Istilah tokoh menunjuk pada orangnya, pelaku cerita. Kemudian jika penokohan, menunjuk pada sifat dan sikap para tokoh seperti yang ditafsirkan oleh pembaca. Penokohan dan karakterisasi sering juga disamakan artinya dengan karakter dan perwatakan menunjuk pada penempatan tokoh-tokoh tertentu dengan watak tertentu dalam sebuah cerita. Atau seperti yang dikatakan oleh Jones (dalam Nurgiyantoro, 2013: 247), penokohan adalah pelukisan gambaran yang jelas tentang seorang yang ditampilkan dalam sebuah cerita.

Tokoh cerita, sebagaimana dikemukakan Abrams (dalam Nurgiyantoro, 2013: 247), adalah orang yang ditampilkan dalam sesuatu karya naratif, atau drama, yang oleh pembaca ditafsirkan memiliki kualitas moral dan kecenderungan tertentu seperti yang diekspresikan dalam ucapan dan apa yang dilakukan dalam tindakan. Dengan demikian, istilah "penokohan" lebih luas pengertiannya daripada "tokoh" sebab ia sekaligus mencangkup masalah siapa tokoh cerita, bagaimana perwatakan dan bagaimana penempatan dan pelukisannya dalam sebuah cerita sehinnga sanggup memberikan gambaran yang jelas.

Dilihat dari segi peran dan pentingnya dalam sebuah cerita tokoh dibedakan menjadi dua yaitu:

(1) Tokoh utama adalah tokoh yang diutamakan penceritaannya dalam novel atau film yang bersangkutan. Karena itu, tokoh utama sangat menentukan perkembangan plot cerita secara keseluruhan (Nurgiyantoro, 2013: 258)

(2) Tokoh tambahan adalah tokoh yang pemunculannya biasanya diabaikan, atau paling tidak mendapatkan perhatian (Nurgiyantoro, 2013: 259)

Berdasarkan perannya tokoh dibagi menjadi dua, yaitu tokoh protagonis dan tokoh antagonis.

(1) Menurut Baldic (dalam Nurgiyantoro, 2013: 261) tokoh protagonis adalah tokoh yang kita kagumi yang salah satu jenisnya secara populer disebut hero. Tokoh yang merupakan pengejawantahan norma-norma nilainilai yang ideal bagi kita

(2) Tokoh antagonis adalah tokoh yang menjadi penyebab terjadinya konflik. Tokoh antagonis adalah tokoh yang beroposisi dengan tokoh protagonist, secara langsung maupun tidak langsung.

\begin{abstract}
Alur
Alur atau plot merupakan unsur fiksi yang penting, bahkan tidak sedikit orang yang menganggapnya sebagai yang terpenting di antara berbagai unsur fiksi yang lain. Untuk menyebut plot, secara tradisional, orang juga sering mempergunakan istilah alur atau jalan cerita, sedangkan dalam teori-teori yang berkembang lebih kemudian dikenal adanya istilah struktur naratif. Sebenarnya, definisi antara alur dan cerita ini mempunyai banyak kemiripan yang banyak membuat orang-orang bingung. Namun jika merujuk pada teori Forster, untuk dapat disebut sebuah alur, maka hubungan antarperistiwa yang dikisahkan itu haruslah bersebab akibat, tidak hanya sekadar berurutan secara kronologis saja.
\end{abstract}

Stanton (2007: 26) misalnya, mengemukakan bahwa alur adalah cerita yang berisi urutan kejadian, namun tiap kejadian itu hanya dihubungkan secara sebab akibat. Peristiwa yang satu disebabkan atau menyebabkan terjadinya peristiwa yang lain. Kenny (dalam Nurgiyantoro, 2013: 167) mengemukakan alur sebagai peristiwaperistiwa yang ditampilkan dalam cerita yang tidak bersifat sederhana karena pengarang menyusun peristiwa-peristiwaitu berdasarkan kaitan sebab akibat. 
Secara teoritis, plot dapat diurutkan atau dikembangkan ke dalam tahap-tahap tertentu secara kronologis, namun dalam praktiknya yang dilakukan pengarang tak selamanya tunduk pada teori itu. Secara teoritis kronologis tahap-tahap pemplotan menurut Tasrif (Dalam Nurgiyantoro, 2013: 149-150) adalah sebagai berikut:

(1) Tahap Situation

Berisi pelukisan dan pengenalam situasi latar dan tokoh cerita. Tahap ini merupakan tahap pembukaan cerita, pemberian informasi awal, dan lain-lain yang terutama berfungsi untuk melandasi cerita yang dikisahkan pada tahap berikutnya.

(2) Tahap Pemunculan Konflik

Masalah dan peristiwa yang menyulut terjadinya konflik mulai dimunculkan. Tahap ini merupakan tahap awalnya munculnya konflik, dan konflik itu sendiri akan berkembang dan atau dikembangkan menjadi konflik pada tahap-tahap berikutnya.

(3) Tahap Peningkatan Konflik

Konflik yang telah dimunculkan pada tahap sebelumya semakin berkembang dan dikembangkan kadar intesitasnya. Peristiwaperistiwa dramatik yang menjadi inti cerita semakin mencekam dan menegangkan. Pada tahap ini konflik hampir mencapai pada klimaks.

(4) Tahap Klimaks

Konflik atau pertentanganpertentangan yang terjadi, yang dilalui dan atau ditimpakan kepada para tokoh cerita mengalami titik intesitas puncak. Klimaks sebuah cerita akan dialami oleh tokoh utama yang berperan sebagai pelaku dan penderita terjadinya konflik utama.

(5) Tahap Penyelesaian

Konflik yang tekah mencapai klimaks diberi penyelesaian, ketegangan dikendorkan. Konflik-konflik yang lain, sub-subkonflik, atau konflik-konflik tambahan, jika ada, juga diberi jalan keluar, cerita diakhiri. Tahap ini berkesesuaian dengan tahap akhir.

Plot dapat dikategorikan ke dalam beberapa jenis yang berbeda berdasarkan sudut-sudut tinjauanatau kriteria yang berbeda. Plot dibedakan berdasarkan urutan waktu, jumlah, dan kepadatan sebagaimana berikut:

(1) Alur Lurus (Progresif)

Alur dikatakan progresif apabila peristiwa-peristiwa yang dikisahkan bersifat kronologis dan berdasarkan urutan kejadian secara runtut. Cerita dimulai dari tahap awal yaitu penyituasian, pengenalan dan pemumculan konflik. Cerita pun dilanjutkan dengan konflik yang semakin meningkat, klimaks, dan sampai pada tahap akhir yaitu penyelesaian.

\section{(2) Alur Kilas Balik (Flashback)}

Alur cerita yang bersifat flashback tidak dimulai dari tahap awal seperti penyituasian atau pengenalan, namun mungkin dimulai dari tahap tangah maupun tahap akhir.

\section{(3) Alur Campuran}

Secara garis besar alur dalam sebuah karya teks naratif mungkin progresif, tetapi didalamnya hampir pasti selalu ada adegan mengenai kisah balik. Demikian pun sebaliknya.

\section{METODE PENELITIAN}

Penelitian ini adalah penelitian deskriptif dan pendekatan penelitian yang digunakan adalah pendekatan kualitatif. Penelitian kualitatif adalah penelitian yang bermaksud untuk memahami fenomena tentang apa yang dialami oleh subjek penelitian dengan cara mendeskripsikannya dengan deskripsi dalam bentuk kata-kata dan bahasa (Moleong, 2015: 6). Data dalam penelitian ini adalah dialog yang didukung dengan adegan yang berhubungan dengan penokohan tokoh utama dan alur pada film Forget Me Not. Sumber Data yang digunakan dalam penelelitian ini adalah film Forget Me Not yang didistribusikan oleh Nikkatsu Studio dan berdurasi 94 menit yang disutradarai oleh Kei Horie. Teknik pengumpulan data dalam penelitian ini adalah menggunakan teknik simak dan teknik catat. 
Tahap analisis data dalam penelitian ini menggunakan metode struktural. Metode struktural digunakan untuk mengetahui unsurunsur yang membentuk keutuhan karya sastra. Metode struktural adalah metode penelitian sastra yang bertindak pada prinsip strukturalisme yang memandang bahwa karya sastra merupakan peristiwa kesenian yang terdiri dari sebuah struktur (Wellek dan Warren, 1990: 159). Untuk mempertajam analisis, penulis menggunakan analisis naratif. Analisis naratif adalah analisis yang melihat teks dari sebuah cerita atau film yang di dalamnya terdapat alur, adegan, tokoh serta karakter (Alfathoni, Minawati, dan Zebua, 2018: 141). Menurut Barker dalam Kustanto (2015 :114), naratif adalah penjelasan yang bertata urut yang mengklaim sebagai rekaman peristiwa, dengan analisis naratif, makna serta nilai-nilai yang terkandung pada sebuah film dapat dipahami. Melalui analisis naratif, struktur cerita dari narasi fiksi seperti novel dan film dapat dikaji (Eriyanto, 2013 :9). Teknik analisis data penelitian ini selaras dengan teori yang dikemukakan oleh Miles dan Huberman (1992: 16) yang meliputi reduksi data, penyajian data, dan tahap penarikan kesimpulan.

\section{HASIL DAN PEMBAHASAN}

Hasil dari penelitian ini berupa analisis penokohan tokoh utama, alur dan relasi antara kedua unsur tersebut dalam film Forget $M e$ Not yang berupa dialog dan adegan pada film tersebut. Berikut akan disajikan penjabaran penokohan tokoh utama, alur dan relasi antara kedua unsur pada film tersebut.

\section{Tokoh}

Tokoh adalah individu-individu yang muncul dalam sebuah cerita (Pujiarto, 2012: 43). Film Forget Me Not sendiri memiliki tokoh-tokoh yang turut serta membangun keutuhan sebuah cerita. Tokoh-tokoh itu diantara adalah Oribe Azusa, Hayama Takashi, Kanae, Hiroki, Takizawa, Iwai-san, Kie-san, Ayah Azusa, dan kakak Hayama. Tokoh-tokoh tersebut dapat dibedakan kembali kedalam beberapa jenis penamaan berdasarkan sudut pandang dan dibagi berdasarkan peran dan pengembangan cerita

\subsection{Berdasarkan Peran dan Pentingnya pada Sebuah Cerita}

Berdasarkan peran dan pentingya pada sebuah cerita, seorang tokoh dapat dibedakan menjadi tokoh utama dan tokoh tambahan. Tokoh utama adalah tokoh yang diutamakan penceritannya dalam sebuah cerita. Ia merupakan tokoh yang paling banyak diceritakan. Baik sebagai pelaku maupun sebagai yang dikenai kejadian (Nurgiyantoro, 2013: 259).

Berdasarkan teori tersebut, tokoh utama pada film Forget Me Not adalah Oribe Azusa dan Hayama Takashi. Oribe Azusa dan Hayama Takashi adalah tokoh penting dalam penceritaan film Forget Me Not, karena kedua tokoh ini adalah tokoh yang paling diutamakan penceritannya. Ini terlihat dari banyaknya adegan dan percakapan yang melibatkan kedua tokoh tersebut. Total 348 data percakapan yang sudah penulis kumpulkan pada film Forget Me Not, Takashi mendapatkan bagian 133 data percakapan dan Azusa sebanyak 93 data percakapan. Jika ditotal, maka data percakapan antara kedua tokoh tersebut adalah berjumlah 226 data dari 348 data percakapan yang didapatkan.

Penulis juga mendapatkan data yang berupa kumpulan adegan-adegan yang terdapat pada film Forget Me Not. Total adegan yang terdapat pada film Forget Me Not berjumlah 139 adegan, dimana Takashi mendapatkan 69 adegan dan Azusa mendapatkan 49 adegan, dimana jika ditotal jumlah adegan antara Takashi dan Azusa adalah berjumlah 118 adegan. Jumlah tersebut merupakan jumlah yang besar, karena hampir sebagian adegan film berisi tentang cerita antara Takashi dan Azusa. Hal tersebut terlihat dari total jumlah adegan kedua tokoh tersebut yang berjumlah 118 dengan jumlah total seluruh 139 adegan yang telah penulis dapatkan.

Berdasarkan jumlah data percakapan dan adegan yang telah didapatkan, dapat 
disimpulkan bahwa Takashi dan Azusa adalah tokoh utama dari film Forget Me Not. Hal ini dikarenakan hampir semua percakapan dan adegan pada film tersebut berisi dan menceritakan tentang Takashi dan Azusa, hal ini pun sesuai dengan teori tentang tokoh utama yang disampaikan oleh Nurgiyantoto (2013: 259) bahwa tokoh utama adalah tokoh yang paling banyak diceritakan dan paling sering muncul.

Selain paling banyak diceritakan, tokoh utama juga selalu berhubungan dengan tokohtokoh lain, ia sangat menentukan perkembangan plot cerita secara keseluruhan. Ia selalu hadir sebagai pelaku, atau yang dikenai kejadian dan konflik (Nurgiyantoro, 2013: 259). Sebagai tokoh utama, peran Takashi dan Azusa dalam cerita film tersebut tentunya sangat penting, karena tanpa kehadiran mereka cerita dalam film Forget Me Not tidak akan terjadi. Kehadiran mereka disini sesuai dengan apa yang dipaparkan oleh Nurgiyantoro yaitu sebagai tokoh yang dikenai kejadian dan konflik utama. Kejadian dan konflik utama dari film Forget Me Not adalah soal melupakan dan dilupakan. Film ini bercerita tentang Takashi yang jatuh cinta kepada seorang gadis bernama Azusa. Azusa bukanlah gadis biasa, ia mengalami kejadian yang tidak biasa yaitu ia dilupakan oleh orangorang disekitar tanpa sebab. Hal tersebut dijelaskan sendiri oleh Azusa kepada Takashi. Berdasarkan hal tersebut, tokoh utama dalam film Forget Me Not adalah Hayama Takashi dan Oribe Azusa.

\section{Penokohan}

Jika tokoh adalah pelaku dalam sebuah cerita, penokohan adalah cara pengarang dalam melukiskan tokoh baik dalam segi watak maupun dalam segi penampilan (Pujiarto, 2012: 44). Penokohan tokoh utama dalam film Forget Me Not adalah sebagaimana berikut:

\subsection{Oribe Azusa}

Oribe Azusa adalah tokoh utama dalam film Forget Me Not. Kehadirannya sebagai tokoh utama sangatlah penting, karena dia-lah pusat dari keseluruhan inti cerita pada film Forget Me Not. Oribe Azusa diceritakan sebagai siswi SMA biasa yang menjalin kisah cinta dengan tokoh utama lainnya yang bernama Hayama Takashi. Azusa berparas cantik dan selalu mengenakan pakaian warna putih setiap kali dia muncul pada sebuah adegan. Oribe Azusa memiliki sifat baik hati, hal itu terlihat disaat siswa-siswa lain menghabiskan waktu liburan musim panas dengan mengikuit les atau bekerja, Azusa lebih memilih untuk membantu dan menjadi relawan di sebuah panti jompo pada adegan dan dialog sebagaimana berikut

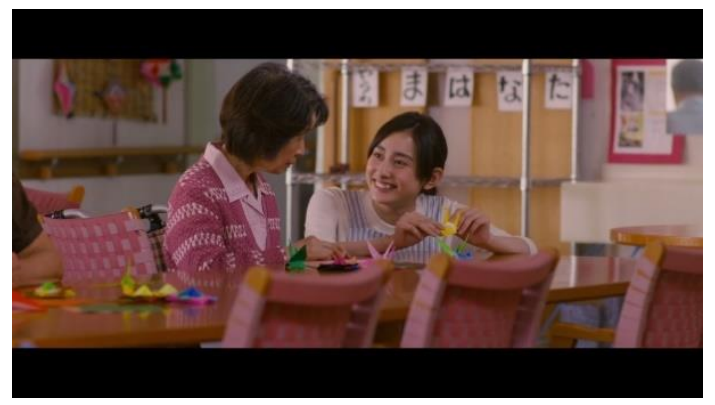

Gambar 1 : Azusa sedang membantu di panti jompo

Dialog 1

Azusa :きえさん、じょする
できたねー
すごい! !
Kie-san,
jyosurudekitane〜
Sugoi!!
'Kie san, sekarang
sudah mahir ya?
Hebat!!’
Kie-san : あなた誰?
Anata dare?
'Anata dare?’
Azusa : 織部です。ボランテ
ィアの織部あずさで
す。
あーいわいさんこん
にちは
Oribe desu. Borantia
no Oribe Azusa desu.
Aa, iwai-san
kon'nichiwa


'Saya Oribe, saya

voluntir disini

namanya Oribe Azusa

Aa, Iwai-san selamat

siang.'

Iwai-san : こんにちは

Konnichiwa

'Selamat siang'

Azusa : きえさん、あなたの

主人ができたよ！！

Kie-san, Anata no

shujin ga dekita yo!!

'Kie-san, suami sudah

datang!!'

Iwai-san：きれいいできたね

Kirei dekitane

'Cantik sekali'

\subsection{Hayama Takashi}

Hayama Takashi adalah pemeran utama dalam film Forget Me Not selain Oribe Azusa. Kehadiran Takashi dalam film ini juga sangatlah penting, karena atas perbuatan Takashi-lah konflik dalam cerita film Forget Me Not sehingga alur dalam . Film tersebut dapat berjalan. Takashi digambarkan sebagai anak laki-laki biasa, dia memiliki teman, keluarga dan menjalani hidup seperti kebanyakan siswa-siswa pada umumnya. Kemudian dia jatuh cinta dengan pemeran utama wanita pada film ini yaitu Oribe Azusa. Hayama Takashi memiliki sifat setia. Hal tersebut terlihat ketika ditanya oleh Kanae tentang siapa yang orang yang Takashi cintai sebagaimana yang terdapat pada dialog berikut

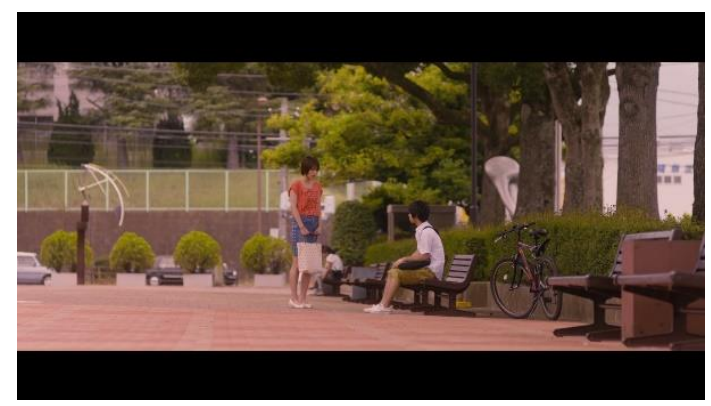

Gambar 2 : Kanae menanyakan siapa yang Takashi cintai

Dialog 2

Kanae : ごめんなら、葉切り
言って。

Gomennara, hakiri itte.

'Maaf, tiba tiba bilang'

Takashi : ごめん

Gomen

Maaf

Kanae : やっぱ好きな人がい

るんだね

Yappa sukina hito ga

irunndane

'Ternyata memang

benar, kamu sudah

punya orang yang

kamu suka'

Takashi : 几え?

Hee?

Kanae : あたしの知ってる人?

学校のかじゃない

の?ね? 誰なの?

Atashi no sitteru hito?

Gakkou ka naino? Ne?

dare nano?

'Apakah aku tahu

orangnya? Satu

sekolah? Siapa

orangnya?'

Pada dialog 2 tersebut Kanae bertanya kepada Takashi tentang siapa orang yang dicintai. Kanae menanyakan hal tersebut karena saat itu Kanae sedang menyatakan perasaan kepada Takashi. Saat akan menjawab pertanyaan tersebut, Takashi terlihat bingung dan tersirat dalam wajah Takashi bahwa dia memiliki seseorang yang dia sukai, tetapi ia tidak bisa mengingatnya. Pada saat dialog itu terjadi, kondisi Takashi sudah lupa tentang Azusa, karena atas dasar tersebut Takashi terlihat bingung saat akan menjawab pertanyaan Kanae.

\section{Alur}

Alur adalah peristiwa-peristiwa dalam sebuah cerita fiksi yang peristiwa-peristiwa tersebut memiliki hubungan kausalitas antara satu dengan yang lainnya (Pujiarto, 2012: 32). Menurut Tasrif (Dalam Nurgiyantoro, 2013: 209) alur memiliki tahapan-tahapan. Tahapan tersebut adalah tahap situation, tahap 
pemunculan konflik, tahap penigkatan konflik, tahap klimaks, dan tahap penyelesaian. Tahaptahap alur dalam film Forget Me Not adalah sebagaimana berikut

\subsection{Tahap Situasi}

Tahap situasi atau penyituasian adalah tahap pengenalan situasi latar dan tokoh-tokoh cerita. Tahap ini merupakan tahap pembukaan cerita dan pemberian informasi awal yang berfungsi untuk melandasi cerita yang akan dikisahkan pada fase selanjutnya. Pada film Forget Me Not, tahap penyituasian sebagian besar terjadi pada awal-awal dimulainya film. Namun tidak menutup kemungkinan tahap penyituasian terjadi di tengah ataupun akhir film. Data yang menunjukan tahap penyituasian adalah data $\mathrm{K} 1_{\mathrm{A}-\mathrm{D}}$. Data $\mathrm{K} 1_{\mathrm{A}-\mathrm{D}}$ memiliki 4 sub-kejadian, yaitu sebagaimana berikut

$\mathrm{K} 1_{\mathrm{A}}$ : Pengenalan latar awal yaitu di sekolah. $\mathrm{K} 1_{\mathrm{B}}$ : Hayama Takashi muncul, ia terlihat sedang murung.

K1C: Teman-teman Takashi muncul mereka menghampiri Takashi

K1D : Kanae mengajak Takashi yang murung untuk berkaraoke.

Data $\mathrm{K} 1_{\mathrm{A}-\mathrm{D}}$ berisi tentang Takashi yang sedang murung karena memikirkan sesuatu di sekolah, dihampiri oleh teman-temannya yaitu Kanae, Hiroki, dan Takizawa yang baru saja selesai mengerjakan ujian. Mengetahui Takashi sedang murung, Kanae mengajak Takashi untuk pergi berkaraoke.

Berdasarkan data $\mathrm{K} 1_{\mathrm{A}-\mathrm{D}}$, sutradara memulai cerita dengan mengenalkan situasi latar dan tokoh-tokoh yang ada di dalam cerita. Sutradara memberikan informasi awal yang akan melandasi cerita selanjutnya, melalui tokoh utama yaitu Takashi. Kemudian sutradara juga mengenalkan tokoh tambahan yang merupakan teman Takashi, yaitu Kanae, Hiroki, dan Takizawa. Mereka semua merupakan siswa SMA.

\subsection{Tahap Pemunculan Konflik}

Tahap pemunculan konflik adalah tahap dimana masalah dan kejadian yang menyulut terjadinya konflik dimunculkan. Tahap ini adalah tahap awal munculnya konflik, yang kemudian konflik tersebut akan berkembang pada tahap berikutnya. Tahap pemunculan konflik biasanya terjadi setelah tahap pengenalan atau penyituasian. Pada film Forget Me Not tahap pemunculan konflik sudah terjadi pada awal film tersebut dimulai. Yaitu ketika tokoh utama pria Takashi bertemu dengan tokoh utama wanita Azusa di persimpangan jalan saat Takashi akan mengembalikan DVD pada data $\mathrm{K} 4_{\mathrm{A}-\mathrm{D}}$. Data $\mathrm{K} 4_{\mathrm{A}-\mathrm{D}}$ terdiri dari 4 sub kejadian sebagaimana berikut

$\mathrm{K} 4_{\mathrm{A}}$ : Takashi pergi menaiki sepeda untuk mengembalikan DVD.

$\mathrm{K} 4_{\mathrm{B}}$ : Di persimpangan jalan, Takashi menabrak seorang gadis.

$\mathrm{K} 4 \mathrm{C}$ : Takashi meminta maaf kepada gadis tersebut, namun gadis tersebut diam saja.

$\mathrm{K} 4_{\mathrm{D}}$ : Takashi mengembalikan kalung yang jatuh, sang gadis segera mengambilnya dan segera pergi

Data $\mathrm{K} 4_{\mathrm{A}-\mathrm{D}}$ berisi tentang pertemuan pertama anatara Takashi dan Azusa pada film Forget Me Not. Dimana Takashi yang hendak mengembalikan DVD secara tidak sengaja menabrak Azusa di persimpangan jalan. Mulai saat itulah, hubungan antara keduanya dimulai. Mengacu pada data $\mathrm{K} 38_{\mathrm{A}-\mathrm{F}}$, yang dimana data tersebut adalah data pada bagian penyituasian. Pada data K38A-F berisi atau menceritakan bagaimana Takashi dan Azusa sebenarnya sudah pernah mengenal dan bahkan mereka berpacaran sebelum pertemuan mereka pada data $\mathrm{K}_{\text {A-D. }}$ Karena konflik pada Forget $\mathrm{Me}$ Not ini adalah tentang dilupakannya Azusa oleh orang-orang termasuk oleh Takashi itu sendiri, maka jika mengacu pada data $\mathrm{K} 4_{\mathrm{A}-\mathrm{D}}$ dan K38A-F Takashi sudah melupakan Azusa sebelum pertemuan mereka berdua terjadi di persimpangan jalan pada awal-awal film. Terlihat bagaimana ekspresi wajah Takashi yang sama sekali tidak mengenali Azusa, dan sebaliknya wajah Azusa yang terkejut karena kembali bertemu dengan Takashi yang sudah melupakannya. Jadi, data $\mathrm{K} 4_{\mathrm{A}-\mathrm{D}}$ selain menjabat sebagai data pada tahap penyituasian, data tersebut juga sekaligus menjabat menjadi 
data pada tahap pemunculan konflik. Karena pertemuan mereka pada data $\mathrm{K} 4_{\mathrm{A}-\mathrm{D}}$ itulah konflik dan cerita pada tahap selanjutnya dapat berkembang.

\subsection{Tahap Peningkatan Konflik}

Tahap peningkatan konflik adalah tahap dimana konflik yang telah dimunculkan ditingkatkan intensitasnya. Peristiwa-peristiwa dramatik yang menjadi inti cerita semakin mencekam dan menegangkan. Pada film Forget Me Not, konflik yang sudah dimunculkan sebelumnya semakin dimunculkan dan diperjelas. Seperti yang terdapat pada data K15 А-B. Data K15 A-в adalah kelanjutan kejadian dari data K14 $\mathrm{A-E}$. Data K15 A-B terdiri dua sub kejadian sebagaimana berikut

K15 A Azusa menjelaskan bahwa dia dilupakan oleh orang-orang.

K15B : Takashi tidak percaya pada hal tersebut, dan dia pun pergi meninggalkan Azusa.

Data K15 terjadi ketika Takashi yang mengejar Azusa setelah ia pergi dari tempat barbeque akhirnya berhasil menyusul Azusa. Kemudian Takashi meminta penjelasan kepada Azusa soal apa yang terjadi, soal kenapa teman-temannya dari kelas tiga $\mathrm{D}$ tidak mengenalinya. Azusa pun menjelaskan kalau semenjak akhir kelas dua, dia dilupakan oleh orang-orang. Mendengar Penjelasan Azusa, Takashi pun tidak mempercayai hal tersebut. Dia pun pergi meninggalkan Azusa.

Data K15 A-B ini adalah data yang memperjelas tentang konflik apa yang sebenarnya terjadi pada film Forget Me Not. Setelah Takashi mengetahui apa yang telah dijelaskan oleh Azusa, konflik yang sebelumnya dimunculkan menjadi meningkat intensitasnya. Hal tersebut membuat cerita semakin kompleks.

\subsection{Tahap Klimaks}

Tahap klimaks adalah tahap dimana konflik atau pertentangan dan yang terjadi mencapai titik puncak. Konlik yang mengalami tahap klimaks tentunya adalah konflik yang terjadi dan ditimpakan kepada para tokoh utama dalam sebuah cerita. Tokoh utama yang mengalami tahap klimaks disini adalah pelaku dan penderita terjadinya sebuah konflik. Pada sebuah cerita, tahap klimaks tidak hanya terjadi sekali saja. Diantara banyaknya klimaks pada sebuah cerita, hanya ada satu yang paling tinggi intensitasnya. Tahap klimaks pada film Forget Me Not terjadi pada data K40A-D. Data tersebut memiliki empat sub kejadian sebagaimana berikut

K40A : Takashi sampai di tempat perjanjian. Ketika sampai disana ia bertemu dengan Azusa. Ketika bertemu dengan Azusa, Takashi sama sekali tidak mengenalinya muka Azusa.

K40в : Disana Azusa menyampaikan pesan seolah-olah dirinya adalah orang lain.

K40C : Setelah menyampaikan pesan, Azusa pun pergi. Takashi tetap tidak mengingat Azusa.

K40D : Tidak sengaja Takashi melihat foto Azusa di hpnya. Kemudian ia sadar bahwa gadis yang berbicaranya dengannya adalah Azusa.

Data K40A-D menceritakan Takashi yang benar-benar sudah lupa tentang Azusa setelah sebelumnya Azusa mengambil memomemo yang tertempel pada kamar Takashi. Takashi ingat bahwa ia memiliki janji untuk menemui Azusa, ia pun pergi saat itu juga sambil menguang-ulang nama Azusa di perjalanannya. Ketika sampai di tempat perjanjian, Takashi akhirnya bertemu dengan Azusa. Saat bertemu Azusa, Takashi tidak mengingat wajah Azusa. Kemudia Azusa menyampaikan pesan kepada Takashi yang mungkin sebagai salam perpisahan untuk terakhir kalinya. Setelah menyampaikan pesan, Azusa pun pergi. Kemudian, tak sengaja Takashi melihat foto Azusa di handphone miliknya. Ia baru sadar bahwa gadis yang berbicara dengannya tadi adalah Azusa. Ia pun menyesal.

Data K40A-D adalah tahap klimaks yang memiliki intensitas tertinggi dari klimaks yang sebelumnya disampaikan oleh penulis. Tahap ini merupakan tahap klimaks tertinggi. Karenakan Takashi yang sebelumnya berjanji tidak akan melupakan Takashi, pada data 
K40 A-D ia benar-benar melupakannya bahkan ia sampai tidak mengenali wajah Azusa.

\subsection{Tahap Penyelesaian}

Tahap penyelesaian adalah dimana konflik yang telah mengalami titik klimaks, diselesaikan dan di turunkan intesitasnya. Tahap penyelesaian adalah dimana cerita yang telah dibangun akan diakhiri dan diselesaikan. Pada film Forget Me Not, setelah tahap klimaks film diakhiri. Seakan-akan film tersebut memiliki ending yang menggantung. Namun, jika kita telaah lebih jauh, tahap klimaks pada film Forget Me Not juga merupakan tahap penyelesaian. Seperti yang diketahui, tahap klimaks yang benar-benar klimaks pada film ini terjadi pada data K40A-D. data K40A-D terjadi pada akhir film dan setelah itu dilanjutkan dengan berakhirnya kisah atau cerita dari film Forget Me Not. Data K40A-D memiliki empat sub kejadian sebagaimana berikut

$\mathrm{K} 40_{\mathrm{A}}$ : Takashi sampai di tempat perjanjian. Ketika sampai disana ia bertemu dengan Azusa. Ketika bertemu dengan Azusa, Takashi sama sekali tidak mengenalinya muka Azusa.

K40в : Disana Azusa menyampaikan pesan seolah-olah dirinya adalah orang lain.

K40C : Setelah menyampaikan pesan, Azusa pun pergi. Takashi tetap tidak mengingat Azusa.

K40 D : Tidak sengaja Takashi melihat foto Azusa di hpnya. Kemudian ia sadar bahwa gadis yang berbicaranya dengannya adalah Azusa

Data K40A-D bercerita bagaimana Takashi berniat menemui Azusa di tempat perjanjian yang sebelumnya Azusa pernah mengatakan bahwa ingin pergi ke tempat itu ketika hari ulang tahunnya. Ketika sampai di tempat tersebut, akhirnya Takashi bertemu dengan Azusa. Namun ketika Takashi melihat Azusa, ia sama sekali tidak mengenalinya, dan malah ia bertanya "dimana Azusa?" kepada Azusa itu sendiri. Mengetahui Takashi yang sudah benar-benar melupakannya, Azusa pun mengucapkan salam perpisahan. Setelah itu, Azusa pun pergi meninggalkan Takashi. Takashi baru menyadari orang tadi adalah Azusa ketika ia tidak sengaja melihat foto
Azusa di handphonenya. Mengetahui hal tersebut, Takashi pun menyesal. Film pun berakhir.

Bagi orang yang hanya melihatnya tanpa memahaminya, pasti orang tersebut akan mengatakan bahwa ending dari film tersebut menggantung karena berakhir saat terjadinya klimaks. Namun ketika ditelaah lebih jauh, bagian klimaks tersebut juga merupakan tahap penyelesaian dari film tersebut. Ini terlihat bagaimana Azusa menyampaikan salam perpisahan kepada Takashi begitu mengetahui bahwa Takashi tidak mengenalinya lagi. Salam perpisahan tersebut merupakan tanda bahwa Azusa ingin mengakhiri semuanya, karena ia mengetahui jika ia memberi kesempatan lagi kepada Takashi, Takashi tetap akan melupakan dirinya. Disini Azusa mengajarkan bagaimana caranya mengikhlaskan, cinta tak harus selalu memiliki. Atas dasar tersebut, penulis menempatkan data $\mathrm{K} 40_{\mathrm{A}-\mathrm{D}}$ sebagai tahap penyelesaian dari film Forget Me Not.

Berdasarkan data dan penjelasanan yang sudah penulis paparkan, dapat dsiimpulkan bahwa alur dari film Forget Me Not adalah alur maju atau progresif. Ini terlihat bagaimana urutan kejadian antara satu dengan yag lain terjadi secara berurutan. Dimulai dari tahap penyituasian sampai tahap penyelesaian, tidak ada alur mundur atau yang lainnya. Karena penceritaan film ini seolah-olah seperti flashback dan juga maju, maka orang akan melihat bahwa film ini memiliki alur campuran.

\section{Relasi Antara Penokohan dan Alur}

Jika mengacu pada teori strukturalisme, maka setiap unsur pada sebuah cerita tidaklah berdiri sendiri, mereka saling terkait satu dengan yang lain menjadi satu kesatuan cerita yang utuh. Unsur-unsur cerita yang dimaksud disini adalah unsur intrinsik yang meliputi Alur, Penokohan, Tema, dan juga Latar. Tak terkecuali pada film Forget Me Not. Film Forget Me Not memiliki unsur-unsur cerita yang saling terkait satu sama lain, khususnya alur dan juga penokohan. Alur pada film Forget Me Not sangatlah penting, begitu juga penokohan tokoh utama yaitu Oribe Azusa dan Hayama Takashi. Kedua unsur saling terkait 
sehingga dapat menghasilkan sebuah cerita yang utuh. Relasi antara kedua unsur tersebut pada film Forget Me Not adalah sebagai berikut

\subsection{Penokohan Mempengaruhi Alur}

Berdasarkan data percakapan P23 dan P25, Azusa memiliki watak yang baik. Itu dikarenakan pada data percakapan tersebut terlihat Azusa lebih memilih menjadi volunteer di panti jompo pada saat liburan musim panas. Karena Azusa memiliki sifat yang baik, ia mau membuka hatinya kembali dan memberi Takashi kesempatan kedua. Maksut kesempatan kedua ini adalah kesempatan menjalin hubungan kembali dengan harapan Takashi tidak akan melupakan Azusa lagi seperti yang terjadi terakhir kali. Seperti yang telah diketahui, Takashi sebelumnya telah melupakan Azusa sewaktu mereka kelas dua SMA.

Setelah mengalami kejadian tersebut, dapat dipastikan Azusa terluka karena ia dilupakan oleh kekasihnya sendiri. Karena terluka, ia pun trauma. Namun karena Azusa memiliki sifat baik, Azusa yang telah terluka dan trauma mau membuka hatinya kembali kepada Takashi dan memberinya kesempatan. Kejadian ini terjadi pada data $\mathrm{K} 8$ A-E. Pada data tersebut berisi Azusa yang sebelumnya enggan memberi tahu namanya kepada Takashi, akhirnya ia memberitahukannya. Dengan syarat Takashi tidak akan melupakannya. Setelah kejadian pada data $\mathrm{K} 8 \mathrm{~A}$-E, alur dalam film Forget Me Not pun berjalan. Jika Azusa tidak baik, maka ia tidak akan memberi kesempatan kedua kepada Takashi dan cerita dari film tersebut akan berhenti saat itu juga.

Penokohan tokoh lain yang mempengaruhi alur adalah penokohan Hayama Takashi. Hayama Takashi memiliki sifat setia. Sifat setia Takashi dapat dilihat bagaimana ia hanya mencintai Azusa, bahkan setelah ia telah melupakan Azusa sebelumnya. Seperti yang diketahui, sebelum pertemuan pertama Takashi dan Azusa pada data percakapan P4 dan data kejadian K4 $4_{\mathrm{A}-\mathrm{D} \text {, }}$ mereka berdua sebenarnya telah saling mengenal dan bahkan mereka telah berpacaran.
Hal tersebut baru disadari oleh Takashi ketika ia membuka laptop pada data percakapan P40 dan data kejadian K39A. Setelah pertemuan pertama mereka pada awal-awal film, Takashi menunjukan bahwa dirinya tertarik dengan Azusa. Hal tersebut disampaikan oleh dirinya sendiri pada data percakapan P6. Jika Takashi tidak setia, mungkin ia tidak akan menyukai Azusa untuk kedua kalinya. Karena Takashi kembali menyukai Azusa, maka alur dalam film Forget Me Not bisa berjalan.

Berdasarkan paparan data dan penjelasana penulis, dapat disimpulkan bahwa unsur cerita yaitu alur dan penokohan pada film Forget Me Not saling mempengaruhi satu sama lain. Hal tersebut terlihat bagaimana penokohan Takashi dan Azusa mempengaruhi dan menuntun jalan cerita dari tahap awal hingga ke tahap akhir

\section{KESIMPULAN}

Berdasarkan hasil analisis yang telah dilakukan oleh penulis, tentang "Relasi Antara Alur dan Penokohan Tokoh Utama dalam Film Forget Me Not" maka dapat diambil kesimpulan bahwa Tokoh utama dalam film Forget Me Not adalah Oribe Azusa dan Hayama Takashi. Oribe Azusa sebagai tokoh utama wanita sedangkan Hayama Takashi sebagai tokoh utama pria. Azusa merupakan tokoh utama wanita karena ia adalah tokoh yang dikenai kejadian konfik utama, sedangkan Takashi merupakan tokoh utama pria karena ia adalah tokoh yang memicu terjadinya konflik.

Oribe Azusa sebagai tokoh utama wanita memiliki sifat baik, dan Hayama Takashi sebagai tokoh utama pria memiliki sifat setia. Alur dalam film Forget Me Not adalah alur progresif atau maju, karena urutan kejadian dari awal sampai akhir sesuai dengan bagan alur progresif yang telah penulis sampaikan pada bab pembahasan. Cerita dimulai dari tahap penyituasian, yaitu pengenalan tokoh utama, tokoh tambahan, latar dan juga setting tempat kejadian film Forget Me Not. Cerita kemudian berlanjut ke 
tahap pengenalan konflik, yaitu dimana Takashi dan Azusa menjalin hubungan kembali setelah sebelumnya Takashi melupakan Azusa. Kemudian ke tahap peningkatan konflik, dimana Takashi yang sudah berjanji akan terus mengingat Azusa akhirnya ia secara perlahan melupakan Azusa. Setelah melewati tahapan-tahapan tersebut, cerita akhirnya sampai di tahap klimaks. Tahap klimaks terjadi ketika Takashi sudah benarbenar melupakan Azusa, dan Azusa memutuskan untuk pergi dan berpisah dengan Takashi. Kejadian Azusa yang pergi meninggalkan Takashi, sekaligus menjadi tahap penyelesaian dalam film Forget Me Not. Alur dan penokohan dalam film Forget Me Not saling berhubungan dan mempengaruhi satu sama lain. Hal tersebut ditunjukan dengan alur yang dari awal dibuat bahwa Azusa sudah dilupakan oleh orangorang, sehingga tokoh Azusa terlihat misterius. Kemudian karena penokohan tokoh Azusa yang baik, hal itu membuat ia mau membuka hatinya kembali kepada Takashi. Karena hal tersebut, alur dan cerita dalam film Forget $M e$ Not bisa berjalan sampai ke tahap akhir.

\section{DAFTAR PUSTAKA}

Ali, Muhammad, Rosta Minawati, Edward Zebua. 2018. "Analisis Unsur Intrinsik pada Film Karma Karya Bullah Lubis”. Dalam Jurnal Proporsi. Volume 3, No 2.

Arikunto, S. 1998. Prosedur Penelitian Suatu Pendekatan Praktek. Jakarta: PT Rineka Cipta.

Arsyad, Azhar. 2002. Media Pembelajaran. Jakarta: Rajawali Pers.

Endraswara, S. 2013. Metologi Penelitian Sastra. Yogyakarta: Center for Academic Publishing Service.

Eriyanto. 2013. Analisis Naratif: Dasar-dasar Penerapan dalam Analisis Teks Berita Media. Jakarta: Kencana Prenada Media Grup.
Faruk. 2012. Metode Penelitian Sastra, Sebuah Penjelajahan Awal. Yogyakarta: Pustaka Pelajar.

Kustanto, Lilik. 2015. "Analisis Naratif: Kemiskinan dalam Program Reality TV "Pemberian Misterius" di Stasiun SCTV". Dalam Jurnal Rekam, Vol 11, No 2. Yogyakarta: ISI Yogyakarta.

Moleong, Lexy J. 2015. Metodologi Penelitian Kualitatif. Bandung: PT. Remaja Rosdakarya.

Miles, B. Mathew dan Michael Huberman. 1992. Analisis Data Kualitatif Buku Sumber Tentang Metode-metode Baru. Jakarta: UIP.

Nurgiyantoro, Burhan. 2013. Teori Pengkajian Fiksi.Yogyakarta: Gadjah Mada Univesity Press.

Pujiarto. 2012. Pengantar Teori Fiksi. Yogyakarta: Penerbit Ombak.

Ratna, Nyoman Kutha. 2010. Teori, Metode, dan Teknik Penelitian Sastra. Yogyakarta: Pustaka Pelajar.

Stanton, Robert. 2007. Teori Fiksi Robert Stanton. Yogyakarta: Pustaka Pelajar.

Suparno, Darsita. 2016. Film Indonesia "Do'a untuk Ayah" Tinjauan Unsur Intrinsik dan Ekstrinsik. Dalam Jurnal Al-Turas. Vol. XXI, No 1. Jakarta: UIN Syarif Hidayatullah.

Susanti, Susi. 2017. "Struktur Sastra Pada Film Rudi Habibie”. Dalam Jurnal Diksastrasia. Volume1, No 2.

Wiyatmi. 2006. Pengantar Kajian Sastra. Yogyakarta: Pustaka Pelajar

Wellek, Renne dan Austin Warren. 1990. Teori Kesustraan (Diterjemahkan Oleh Melani Budianta). Jakarta: Pustaka Jaya.

Zazila, Dharazatun. 2013. Analisis StrukturalSemiotik Teks Film Des Hommes et Des Dieux Karya Xavier Beauvois. Yogyakarta: Universitas Negeri Yogyakarta. 